dr hab. Aldona Barbara PODOLSKA-MEDUCKA, prof. SGH

Kolegium Ekonomiczno-Społeczne, Szkoła Główna Handlowa w Warszawie

e-mail: apodol@sgh.waw.pl

ORCID: 0000-0003-0046-8917

DOI: $10.15290 /$ OES.2021.03.105.05

\title{
GENEZA I CHARAKTERYSTYKA PRAWA ZAMÓWIEŃ PUBLICZNYCH W POLSCE MIĘDZYWOJENNEJ ${ }^{1}$
}

\begin{abstract}
Streszczenie
Cel - Celem opracowania jest charakterystyka prawa zamówień publicznych w Polsce międzywojennej, która poprzedzona została jego genezą. Istotne znaczenie prawa regulującego proces wydatkowania środków publicznych wynikało z faktu, że środki te w dużej części pochodziły z budżetu państwa, a sektor publiczny był bardzo ważnym klientem na rynku krajowym. Przyjęte rozwiązania musiały uwzględniać problemy gospodarcze państwa polskiego w omawianym okresie.

Metoda badan - Wykorzystano analizę przepisów prawa i materiałów parlamentarnych oraz dokonano przeglądu literatury.

Wynik - Przedwojenne polskie prawo zamówień publicznych tworzone było w trudnej sytuacji gospodarczej państwa. Ustawodawca musiał to uwzględniać i stworzyć odpowiednie warunki na krajowym rynku przede wszystkim dla polskich przedsiębiorców. W latach dwudziestych wykorzystywano regulacje prawne dawnych państw zaborczych. Lata trzydzieste przyniosły już ustawodawstwo jednolite dla całego państwa.

Oryginalność / wartość / implikacje / rekomendacje - Zamówienia publiczne są bardzo ważnym elementem finansów publicznych. Zasady je organizujące, zawarte w regulacjach prawnych, stanowią niezbędny element przejrzystości wydatkowania środków publicznych. Przedwojenne prawo zamówień publicznych stało się podstawą rozwiązań przyjętych w Polsce po 1989 r.
\end{abstract}

Słowa kluczowe: finanse publiczne, zamówienia publiczne, prawo gospodarcze, II Rzeczypospolita

\section{POLISH INTERWAR PUBLIC PROCUREMENT LAW - GENESIS AND ESSENCE}

\section{Summary}

Puppose - The purpose of this paper is to describe the public procurement law in the interwar Poland, preceded by its genesis. The significance of the law regulating the process of public funds expenditure derived from these funds coming largely from the state budget, and the public sector being a very important client on the domestic market. The adopted solutions had to take into account economic problems of the Polish state in the discussed period.

1 Artykuł wpłyną 3 maja 2021 r., zaakceptowano 15 czerwca 2021 r.

Tekst jest jednym z kilku przygotowywanych opracowań dotyczących funkcjonowania zamówień publicznych w Polsce przed wojna, ukierunkowanych na potrzeby wojska w czasie pokoju. Na temat realizacji zamówień wojska w czasie wojny [Podolska-Meducka, 2011]. 
Research method - Legislative and parliamentary material analysis was conducted, and a literature review was undertaken.

Result - The pre-war Polish procurement law was enacted in a difficult domestic economic context. The legislator had to account for this and establish appropriate domestic market conditions, primarily for Polish entrepreneurs. In the 1920s, the legal regulations of the former partitioning states were applied. The 1930s brought uniform legislation for the entire country.

Originality / value / implications / recommendations - Public procurement is a very important element of public finance. The rules that organize it, embodied in legal regulations, are an essential part of public funds spending transparency. Pre-war public procurement law became the basis for solutions adopted in Poland after the year 1989.

Keywords: public finance, public procurement, economic law, Second Republic of Poland

JEL classification: H50, K20, N44

\section{Wstęp}

W Polsce międzywojennej sektor publiczny był bardzo ważnym klientem na rynku krajowym. Nawet w okresie najdalej posuniętych oszczędności, czyli w trakcie kryzysu gospodarczego lat trzydziestych, zakupy tego sektora przekraczały rocznie kwotę 1 mld zł [Przepisy o dostawach..., 1937, s. 3]. Przeznaczone na ten cel środki pochodziły głównie z budżetu państwa i stąd konieczność ich wydatkowania zgodnie $z$ przejrzystymi regułami. Zamówienia publiczne, nazywane wtedy dostawami i robotami (usługami) lub zamówieniami rządowymi, stanowiły ważną część polityki gospodarczej państwa. Prawo regulujące ten obszar jego aktywności było istotnym elementem całego systemu prawnego. Jak w przypadku wielu innych dziedzin prawa, w tym gospodarczego, w latach dwudziestych obowiązywało w tej materii dawne prawo zaborcze. W wyniku działań unifikacyjnych początek lat trzydziestych przyniósł regulację ustawową, którą kilka lat później uzupełniono przepisami wykonawczymi.

\section{Próby centralizacji zamówień rządowych}

Po odzyskaniu niepodległości starano się w Polsce stworzyć centralny system zaopatrywania struktur państwa w dobra konieczne do prawidłowego funkcjonowania. Już w grudniu 1918 r. powołano Urząd Rozdzielczy, który realizował ideę centralizacji zamówień rządowych [Dekret, 1918]. Powstał on przy Ministerstwie Przemysłu i Handlu $(\mathrm{MPiH})$, chodziło bowiem przede wszystkim o zamówienia na wyroby przemysłowe. Wszystkie organy rządowe miały obowiązek przekazywania swoich potrzeb do nowo powstałej instytucji, która w celu realizacji kierowała zlecenia do konkretnych zakładów przemysłowych. Przewodniczącego urzędu powoływał minister stojący na czele resortu, a w jego skład wchodzili przedstawiciele ministerstw: przemysłu i handlu, rolnictwa i dóbr państwowych, spraw wojskowych, aprowizacji, robót publicznych, komunikacji, poczt i telegrafów oraz skarbu. 
Powstanie tej instytucji było przejawem, charakterystycznego m.in. dla pierwszych lat niepodległości, interwencjonizmu państwowego. Wymuszony on został okolicznościami związanymi z koniecznością odbudowy i budowy infrastruktury gospodarczej oraz struktur państwa w trudnych powojennych czasach. Urząd rozwiązano na początku $1920 \mathrm{r}$. Uznano, że jedna instytucja nie była już w stanie koordynować akcji centralnego (w założeniu racjonalnego) obsługiwania poszczególnych urzędów państwowych w zakresie realizacji ich zamówień [Uchwała, 1920].

Ze względu na specyfikę własnych zamówień niektóre resorty od początku mogły liczyć na autonomię w zakresie wydatkowania środków publicznych. Tak było w przypadku Ministerstwa Spraw Wojskowych (MSWojsk.). Z powodu wojny z bolszewikami wydatki na wojsko miały tendencję stale wzrastająca $i$ zdecydowanie dominowały w budżecie państwa - w 1920 r. wyniosły 59\% ogółu wydatków [Pączewski, 1921, s. 720]. W kolejnych latach gospodarka wojskowa utrzymała pozycję najważniejszego klienta Skarbu Państwa [Kłoczewski, 1987, s. 13]. W kwietniu 1919 r. powołano Główny Urząd Zaopatrywania Armii (GUZA) [Ustawa, 1919b; Regulamin..., 1919], co miało zapobiec wszelkim opóźnieniom w zaprowiantowaniu walczącego na froncie wojska. Była to samodzielna instytucja cywilna, która otrzymała rozległe uprawnienia $\mathrm{w}$ zakresie materiałowego zaopatrzenia armii i wspierania zakładów pracujących dla wojska. Rozdzielała zamówienia między poszczególnych dostawców i podpisywała z nimi umowy. Zakupy żywności i paszy realizowano $\mathrm{w}$ porozumieniu $\mathrm{z}$ Ministerstwem Aprowizacji, co nie zapobiegło sporom kompetencyjnym między wojskiem a strukturami cywilnymi i doprowadziło w grudniu 1920 r. do likwidacji GUZA. Zakres jego obowiązków przejął Departament Gospodarczy MSWojsk [Ustawa, 1920].

Instytucjonalne próby scentralizowania zamówień rządowych z początków niepodległej państwowości nie dały oczekiwanych rezultatów. Każdy resort musiał sobie radzić we własnym zakresie. Jako podstawę prawną wykorzystywano dawne ustawodawstwo zaborcze, czyli rosyjską ustawę z 1900 r. o dostawach i robotach rządowych, pruskie rozporządzenie z 1906 r. o udzielaniu zamówień na dostawy i roboty oraz austriackie rozporządzenie z 1909 r., dotyczące oddawania w przedsiębiorstwo dostaw i robót państwowych ${ }^{2}$. Pod koniec 1930 r. podjęto kolejną próbę centralizacji i powołano międzyministerialną komisję do uzgadniania zamówień rządowych na rok budżetowy 1931/1932, umocowaną ponownie przy MPiH [Partyka, 1931, s. 25]. Stroną inicjująca był Komitet Ekonomiczny Ministrów (KEM), który koordynował politykę gospodarczą państwa. Jego aktywność w tej kwestii wynikała z trudnej sytuacji gospodarczej, która przyniósł ze sobą kryzys. Silny spadek produkcji przemysłowej powodował redukcję liczby zatrudnionych ${ }^{3}$. W uchwale przyjęto założenie, że uzgadnianie z komisja rocznych programów zamówień wszystkich instytucji państwowych i samorządowych pod kątem

2 Ze względu na ograniczoną objętość artykułu regulacje zaborcze nie będą przedmiotem omówienia. $\mathrm{Na}$ ten temat powstaje oddzielny tekst.

3 W latach 1929-1932 w wielkim i średnim przemyśle pracę straciło 36\% zatrudnionych, w całym przemyśle było to $29 \%$ [Landau, 1989, s. 369]. 
równomiernego rozłożenia krajowej produkcji przemysłowej w czasie i na poszczególne gałęzie przemysłu będzie najlepszą metodą wykorzystania ich w walce z bezrobociem. Poszczególne instytucje miały obowiązek zgłaszać komisji wszystkie zamówienia o wartości przekraczającej 50 tys. zł. Próg ten KEM ustanowił w 1932 r. [Żelaski, 1937, s. 49]. We własnym zakresie przeprowadzały postępowania przetargowe, przesyłały komisji protokoły przetargowe oraz własne propozycje przedsiębiorstw, które mogły zrealizować zamówienie. Dzięki temu mogła ona sugerować, do których okręgów przemysłowych i konkretnych zakładów kierować bieżące zamówienia [Partyka, 1931, s. 25]. Spod jej kompetencji wyłączono zakupy materiałów: opatentowanych, produkowanych przez kartele ${ }^{4}$, wytwarzanych w kraju przez jednego przedsiębiorcę oraz pochodzenia zagranicznego. Przyjęcie takiego rozwiązania podważało dwie zasady dominujące dotychczas w wykorzystywanej przy realizacji zamówień procedurze przetargowej - wyboru najtańszej oferty oraz niedzielenia zamówienia między poszczególnych wykonawców. Rząd zyskiwał ogromny wpływ na kierunek strumienia środków publicznych kierowanych na rynek. Bez materiałów dokumentujących prace komisji nie można zbadać efektów i skuteczności jej działań. Trudno określić np. to, jaką w wyniku jej działalności część środków publicznych kierowano do sektora państwowego, wspierając go w czasie kryzysu, a jaka płynęła do sektora prywatnego. Komisję powołano pierwotnie na jeden rok budżetowy, ale przetrwała ona przez kilka następnych lat [Żelaski, 1937, s. 50].

\section{Pierwsze projekty zmian}

Świadomość konieczności wypracowania jednolitego dla całego kraju rozwiązania, które zaspokajałoby aktualne potrzeby, spowodowała, że od początku lat dwudziestych toczyły się prace nad przygotowaniem projektu ustawy o zamówieniach publicznych. Pierwszy opracowany został już w 1920 r. [Projekt..., 1927, s. 109]. Podjęła się tego Prokuratoria Generalna RP, która powstała rok wcześniej w celu obsługi prawnej Skarbu Państwa, instytucji i przedsiębiorstw państwowych oraz zakładów finansowanych przez państwo [Dekret, 1919; Ustawa, 1919a]. Nie zachował się tekst projektu, nie można więc dokonać jego analizy. Można natomiast domniemywać, że przygotowanie go w środowisku pozaministerialnym, które słynęło z prawniczego profesjonalizmu i dbałości o interes publiczny, dawało gwarancję dobrego prawa. Projekt był przedmiotem dyskusji w Prezydium Rady Ministrów i poszczególnych ministerstwach, ale nie trafił do Sejmu Ustawodawczego [Projekt..., 1927, s. 110]. Wydaje się, że czas wojenny temu nie sprzyjał.

Brak jednolitych przepisów dawał się we znaki przedsiębiorcom, którzy musieli śledzić na bieżąco różne doraźne ministerialne regulacje. Każdy resort opracowywał swoje, uwzględniając charakter własnych zamówień oraz dopasowując ustawodawstwo zaborcze do realiów polskiej gospodarki. Liderem było MSWojsk., które

\footnotetext{
4 W 1929 r. kartelizacja objęła w Polsce około 40\% produkcji przemysłowej i stale rosła [Zweig, 1944, s. 103]. W 1938 r. było to już 75\% produkcji przemysłu wielkiego i średniego [Landau, 1974, s. 815].
} 
tworzyło najwięcej szczegółowych instrukcji. Wynikało to ze specyfiki zamówień wojskowych oraz roli, jaką armia odgrywała w Polsce międzywojennej. Położenie geopolityczne kraju wymagało odpowiedniego przygotowania do realizacji stale rosnących potrzeb wojska. Przykładem takiej instrukcji, która powstała już po wojnie $z$ bolszewikami i miała stanowić podstawę prawną do obsługi zamówień udzielanych w czasie pokoju, były Przepisy o dostawach wojskonych z 1922 r. [1923]. Wyraźnie w niej stwierdzano, że „przepisy te nie odnoszą się jednak do umów o dostawy wojskowe, zawieranych w czasie wojny lub po ogłoszeniu mobilizacji”" [Przepisy..., 1923, s. 7]. Oznaczało to, że dla dostaw wojennych przewidziany był szczególny tryb, który planowano zawrzeć w tzw. gospodarczej konstytucji obrony państwa. Określenie to pojawiło się w $1927 \mathrm{r}$. Rozumiano pod nim pakiet tzw. ustaw wojennych, czyli regulacji dotyczących m.in. stanu wojennego czy świadczeń wojennych ludności [Sosabowski, 1927; Podolska-Meducka, 2008]. Celem instrukcji było „ustalenie tych rodzajów zakupów, jakie obowiązują w wojsku, jako też sposobu przeprowadzenia każdego $\mathrm{z}$ nich, następnie zaś ustalenie dla całego personelu wojska, powołanego do zawierania umów, formy, w jaką muszą być ujęte umowy, zawierane w poszczególnych wypadkach, warunków technicznych, które muszą być wypełnione przy zakupie materiałów wojskowych, sposobu ich odbioru, jak również określenia ilości, miejsca i terminu dostawy, wysokości cen oraz sposobu zapłaty" [Przepisy..., 1923, s. 5]. Jako dostawy wojskowe rozumiano zakupy realizowane na podstawie umów zawieranych przez władze wojskowe, dowództwa, urzędy i inne organy podległe MSWojsk. z osobami trzecimi (dostawcami), których przedmiotem było dostarczenie wojsku niezbędnych towarów lub wykonanie na rzecz armii pewnych prac (usług). Instrukcja była bardzo obszerna (93 art.) i wyposażona w kilkanaście załączników, w których zawarto wzory najważniejszych dokumentów, np. wezwania do składania ofert, protokołu rozprawy ofertowej, zawiadomienia o przyjęciu oferty, umowy na realizację zamówienia czy protokołu jego odbioru.

W instrukcji znalazły odbicie trzy najważniejsze zasady, które legły u podstaw procedury udzielania zamówień publicznych, nie tylko wojskowych. Priorytetowy był wybór dostawcy lub wykonawcy w drodze przetargu nieograniczonego, co miało dawać gwarancję stworzenia optymalnych warunków dla wolnej konkurencji. Zasadą było również powierzanie zamówienia jednemu oferentowi, czyli niedzielenie zamówienia. Najważniejszą rolę odgrywała zasada wyboru najtańszej oferty. Praktyka zdecydowała jednak, że zasady te trzeba było weryfikować. Szczególnie wyraźnie widać to na przykładzie dostaw dla wojska. Specyfika tych dostaw powodowała, że przetarg ograniczony był często bardziej racjonalny. Jak pisał w 1931 r. znawca rynku dostaw wojskowych, K. Partyka [1931, s. 23]: „Przy tyloletnim doświadczeniu, wyniesionym $z$ przetargów nieograniczonych, gdy przy dostawach artykułów zaopatrzenia wojska, przesunęły się właściwie wszystkie poważniejsze firmy danej branży, mamy dostateczną znajomość firm i znamy ich zdolność produkcyjną. Szukać ich za pomocą ogłoszeń w dziennikach nie potrzebujemy. Te, które dotąd nie dostarczały, a czują się na siłach podołaniu obowiazkom, same do nas zgłosza się. Przetargów nieograniczonych nie potrzebujemy. Ceny artykułów zaopatrzenia ustaliły się od szeregu lat, mamy organa fachowe, sprawdzające kalkulację potrzeb- 
nych nam materiałów, wyzysku ze strony oferentów nie obawiamy się. Ani żadnej umowy zmowy, ani żadnych oficjalnych przedstawicielstw interesów". Wielki kryzys gospodarczy w innym świetle postawił też zasadę o niedzieleniu zamówień. Odchodzenie od niej wymuszało rosnące bezrobocie: „W dobie bezrobocia, gdy państwo ponosi olbrzymie ciężary na zasiłki dla bezrobotnych, dostawy rządowe muszą być dzielone i skierowywane tam przede wszystkim, gdzie bezrobocie najbardziej się sroży” [Partyka, 1931, s. 24]. Również wybór najtańszej oferty budził wiele gorących dyskusji: „Dziś nie może być zasada, kto najtaniej - lecz kto najsolidniej i najbardziej - ze względu na interesy państwowe - korzystnie. Cena to oczywiście kwestia ważna, lecz nie najważniejsza. Niska cena to co najwyżej chwilowa tylko, doraźna korzyść Skarbu Państwa. Są ważniejsze, na dłuższą metę obliczone, względy. A temi są rentowność przedsiębiorstw [...]. Pod tym bowiem warunkiem może przedsiębiorstwo prosperować i zatrudniać rzesze robotnicze" [Partyka, 1931, s. 22].

Konieczność zapoznania się z obszerną dokumentacją, którą przedstawiał każdy z podmiotów publicznych i której znajomość była niezbędna do starania się o zamówienie, powodowała coraz częstsze dyskusje na temat zawiłości i obszerności procedur. Domagano się ich uproszczenia i ujednolicenia. Rządowe przetargi budziły wiele emocji. Otaczała je ,atmosfera plotek i nieufności” [Partyka, 1931, s. 21]. Pogodzenie różnych i często sprzecznych interesów było bardzo trudne. W 1927 r. pojawił się kolejny projekt ustawy, który tym razem przygotowano w MPiH. Jego tekst również się nie zachował, ale znany jest z opracowania. Składał się z 28 art. i odnosił nie tylko do zamówień dla administracji państwowej sensu stricto, ale obejmował także państwowe monopole, przedsiębiorstwa, zakłady i fundusze. Bezwzględna przewage zapewniono w nim przetargowi nieograniczonemu [Projekt..., 1927, s. 109-110]. W poszczególnych etapach postępowania zawarto: publiczne wezwanie do składania ofert (zamieszczane przez zamawiającego w Monitorze Polskim, z przesłaniem streszczenia wojewodom - w celu powiadomienia o zamówieniu miejscowych sfer gospodarczych) oraz organizację prac komisji ofertowej i przetargowej. Dla starającego się o zamówienie (oferenta) ważną kwestią była konieczność wpłacenia wadium, które stanowiło materialne zabezpieczenie dla zamawiającego na czas postępowania ${ }^{5}$. Jego wysokość mogła wynosić od 0,3 do 10\% wartości zamówienia [Projekt..., 1927, s. 110]. Trzyosobową komisję ofertową powoływał zamawiający w celu wyłonienia tych ofert, które przechodziły do dalszego etapu postępowania. Przed ukończeniem jej prac oferent mógł zmienić, uzupełnić lub wycofać ofertę. Odrzuceniu podlegały te oferty, które były: składane przez osoby pozbawione zdolności do czynności prawnych, doręczone po czasie, nieodpowiadające warunkom danego przetargu, złożone bez wpłacenia wadium, zawierające braki formalne (np. niepodpisane), a także nieza-

\footnotetext{
${ }^{5}$ Jako wadium zazwyczaj przyjmowane były gotówka oraz obligacje państwowych lub komunalnych pożyczek oraz inne papiery wartościowe. Państwowe papiery wartościowe, listy zastawne i obligacje państwowych instytucji kredytowych oraz listy zastawne instytucji kredytowych prywatnych, ale gwarantowanych przez państwo, przyjmowane były po kursie publikowanym przez Ministerstwo Skarbu [Dostany..., 1939, s. 61-62].
} 
wierające wyraźnie określonej ceny wykonania zamówienia. Odrzucić należało także oferty osób karanych za korupcję lub spokrewnionych (spowinowaconych) z pracownikami instytucji zaangażowanych w przeprowadzenie przetargu $[$ Projekt..., 1927, s. 111].

Wybrane oferty podlegały ocenie przez komisję przetargową. Pod tą nazwa, na tym etapie postępowania, funkcjonowała dotychczasowa komisja ofertowa. Po rozpatrzeniu wszystkich ofert i wysłuchaniu opinii rzeczoznawców komisja większością głosów wybierała najlepszą ofertę. Jeśli takiej nie było, wnioskowano o ponowne ogłoszenie wezwania do składania ofert [Projekt..., 1927, s. 112]. Wyłoniony kontrahent nie mógł liczyć na żadne finansowe wsparcie w postaci zaliczek czy pożyczek na poczet przyszłego wynagrodzenia za realizację zamówienia oraz wsparcie materiałowe, które ewentualnie wynikałoby ze specyfiki zamówienia [Projekt..., 1927, s. 112].

Przetarg ograniczony przewidziano dla zamówień z ograniczonym kręgiem wykonawców lub takich, które zrealizować mógł tylko konkretny wykonawca. Procedurę bezprzetargową (zamówienia z wolnej ręki) zarezerwowano dla wyjątkowych przypadków: interes publiczny wymagał natychmiastowego wykonania zamówienia (np. w sytuacji klęski żywiołowej), istniał ważny wzgląd na dobro publiczne (np. zachowanie tajemnicy państwowej), wartość zamówienia nie przekraczała 500 zł, uprzedni dwukrotny przetarg nie przyniósł rozstrzygnięcia lub wynik przetargu został uznany za niekorzystny dla Skarbu Państwa [Projekt..., 1927, s. 110].

Projekt charakteryzował się troską o maksymalne zabezpieczenie interesów Skarbu Państwa. Jej przejawem był priorytet przetargu nieograniczonego, dość wysoka stawka wadium oraz wykluczenie wszelkich form bezpośredniej (lub pośredniej) pomocy dla wyłonionego wykonawcy zamówienia. Ochronie rynku krajowego, co było wyrazem działań protekcyjnych rządu, służyć miała zasada preferencji dla zamówień krajowych. Domagano się tego od rządu: „Takie zabezpieczenie interesów przemysłu rodzimego służy usamodzielnieniu kraju i sprzyja rozwojowi wytwórczości w tych wszystkich gałęziach produkcji, które w miarę uprzemysławiania się państwa przejmować będą na siebie dotychczasową klientelę producentów obcych, a którym cła ochronne nie zawsze - zwłaszcza w okresie nasilenia walki konkurencyjnej - zabezpieczają dostateczną opiekę. Oferent, opowiadający się w tej walce za produkcją obca, nie zasługuje na poparcie: udzielenie mu zamówienia równa się uszczupleniu rynków zbytu dla własnej produkcji” [Projekt..., 1927, s. 111-112]. Bardzo ważną kwestią w projekcie było wyłączenie z zakresu przyszłej ustawy zamówień wojskowych [Projekt..., 1927, s. 108]. Armia miała w tym względzie posługiwać się własnymi przepisami wewnętrznymi.

Pomimo przygotowania projektu nie wszedł on pod koniec lat dwudziestych na drogę ustawodawcza. Tak się działo z wieloma propozycjami zmian z obszaru m.in. prawa gospodarczego, które pojawiały się w tym okresie. Dopiero kryzys gospodarczy intensyfikował działania przynoszące ostatecznie konkretne rozwiązania prawne. Również w przypadku zamówień publicznych musiało upłynąc kilka lat, zanim sprawa powróciła. 


\section{Ustawa o dostawach i robotach na rzecz Skarbu Państwa, samorządu oraz instytucji prawa publicznego}

Projekt ustawy powrócił po czterech latach. Można domniemywać, że był to ten sam dokument, który pojawił się w 1927 r., ponieważ inicjatywa ustawodawcza ponownie wyszła na forum rządu z MPiH. Rada Ministrów przyjęła go 24 sierpnia 1931 r. jako projekt rządowy i przesłała do Sejmu. W uzasadnieniu pojawił się tylko jeden powód przygotowania tej regulacji: „Interes Skarbu Państwa i sfer gospodarczych wymaga pewnego stałego i jednolitego uregulowania sprawy dostaw i robót rządowych przez wydanie odpowiednich ogólnych przepisów, obowiązujących dla wszystkich resortów administracji państwowej, po uchyleniu dotychczasowych przepisów b. państw zaborczych" [Sejm RP III okresu, Druk nr 307]. Pierwsze czytanie odbyło się 20 październiku 1931 r. [Sprawozdanie, 1931, ł. 60], następnie przez ponad rok projekt leżał w Komisji Skarbowej, a 13 grudnia kolejnego roku został wycofany [Sprawozdanie, 1932, ł. 3]. W tym czasie nowy projekt, zatwierdzony przez rząd 5 grudnia 1932 r., był już w Sejmie [Sejm RP III okresu, Druk nr 617]. Nieco obszerniejszy od swojego poprzednika, przynosił rozszerzenie i definicyjne uszczególowienie kręgu podmiotów, które mogły dokonywać zamówień. Widać to było już w samym jego tytule, który brzmiał Rzqdony projekt ustany o dostawach i robotach na rzecz. Skarbu Państwa, samorzadu oraz instytuci prawa publicznego, podczas gdy pierwszy zatytułowano Rzqdowy projekt ustany o dostawach i robotach państwonych. W projekcie uwzględniono zamówienia wojskowe. Formalna różnica polegała także na powierzeniu pieczy nad wykonaniem przyszłej ustawy nie premierowi (pierwszy projekt), tylko ministrowi przemysłu i handlu (drugi projekt), którego obarczono odpowiedzialnością za sprawną implementację nowego prawa do rzeczywistości gospodarczej.

Posłowie pracowali nad nowym projektem 13 grudnia [Sprawozdanie, 1932, 1. 24-25]. Komisja Skarbowa miała półtora miesiąca na przygotowanie sprawozdania, bo 27 stycznia 1933 r. odbyło się drugie czytanie, a następnie projekt przegłosowano [Sprawozdanie, 1933b, 1. 8-10]. Uchwalona ustawa od razu trafiła do Senatu, gdzie zajęła się nią Komisja Gospodarstwa Społecznego. Przyjęcie sprawozdania komisji i głosowanie nad ustawą nastąpiło 15 lutego [Sprawozdanie, 1933a, 1. 5-7]. Weszła w życie z dniem ogłoszenia, czyli 24 marca. W trakcie prac parlamentarnych wśród posłów i senatorów panowało przekonanie, że taka ustawa powinna zostać uchwalona. Podkreślano konieczność zastosowania zasady preferencji krajowych, która chroniłaby polskich wykonawców oraz wyeliminowania kosztownego pośrednictwa między zamawiającym a wykonawca [Sprawozdanie, 1933b, ł. 8-9]. Protestowano również przeciwko faworyzowaniu warszawskich wykonawców przy dokonywaniu wyboru najlepszej oferty [Sprawozdanie, 1933a, ł. 6].

Ustawa o dostawach i robotach na rzecz Skarbu Państwa, samorządu oraz instytucji prawa publicznego [Ustawa, 1933] miała charakter ramowy i składała się jedynie z pięciu artykułów. Ustalenie procedury udzielania zamówień powierzono rządowi $\mathrm{i}$ nastapić to miało $\mathrm{w}$ drodze wydania odpowiednich rozporządzeń. W świetle przepisów ustawy zamawiającym mógł być Skarb Państwa, samorząd 
terytorialny, instytucje prawa publicznego ${ }^{6}$, zakłady $^{7}$ i przedsiębiorstwa państwowe oraz zakłady ${ }^{8}$ i fundusze ${ }^{9}$ zarządzane przez państwo. Nie mogły zaś być monopole państwowe ${ }^{10}$ oraz państwowe przedsiębiorstwa przemysłowe, handlowe i górnicze, które zostały wydzielone z ogólnej administracji państwowej i skomercjalizowane ${ }^{11}$. W przypadku tej grupy podmiotów ustawodawca zobowiazzał rząd do wydania specjalnych przepisów, które miały regulować warunki zamówień. W granicach odpowiednich upoważnień poszczególni ministrowie mieli prawo wydawania własnych przepisów dla podległych im działów administracji państwowej oraz nadzorowanych przez nich instytucji. Warunkiem było jednak porozumienie w tej materii z ministrami przemysłu i handlu oraz skarbu [Żelaski, 1937, s. 9]. Dla administracji państwowej ogólnej oraz samorządu terytorialnego przepisy szczegółowe wydawać mógł minister spraw wewnętrznych w porozumieniu z ministrami przemysłu i handlu oraz skarbu i, ewentualnie, $z$ innymi ministrami.

Wykonawcą zamówienia mogło zostać przedsiębiorstwo krajowe mające siedzibę na terenie kraju. Jego właściciel nie musiał mieć polskiego obywatelstwa. Mogły nim zostać także przedsiębiorstwa zagraniczne, spełniające warunki: rejestracji i dopuszczenia do działalności na terenie Polski oraz zaangażowania w Polsce przynajmniej części własnego kapitału ${ }^{12}$.

${ }^{6}$ Instytucje prawa publicznego to organy o określonym zakresie działania, mające znaczenie dla interesu państwowego lub społecznego, np. powołany w 1927 r. Powszechny Zakład Ubezpieczeń Wzajemnych (od 1952 r. - Państwowy Zakład Ubezpieczeń). Instytucja ta zajmowała się przymusowymi ubezpieczeniami nieruchomości i ruchomości od ognia, plonów od gradobicia, a żywego inwentarza od pomoru. Od 1933 r. w jej gestii były wszystkie rodzaje ubezpieczeń, oprócz ubezpieczeń na życie [Encyklopedia..., 1999, s. 335].

7 Zakłady państwowe to instytucje wyposażone przez państwo w środki finansowe na realizację określonych zadań, np. szkoły i szpitale.

${ }^{8}$ Zakłady zarządzane przez państwo to zakłady prywatne, które zostały przejęte przez administrację państwową, np. za długi względem Skarbu Państwa.

${ }_{9}$ Fundusze zarządzane przez państwo to głównie fundusze społeczne, niefigurujące w budżecie państwowym, ale związane z interesem państwa, np. utworzony w 1933 r. Fundusz Obrony Morskiej, którego celem było gromadzenie środków na rozbudowę marynarki wojennej ze składek społeczeństwa polskiego w kraju i za granica.

${ }^{10}$ Monopole państwowe to przedsiębiorstwa funkcjonujące na zasadzie wyłączności państwowej, czyli w przypadku których państwo zastrzegało sobie prawo wyłącznej produkcji lub sprzedaży, np. Państwowy Monopol Spirytusowy i Państwowy Monopol Zapałczany [Grata, 2009].

11 W tym przypadku podstawą było rozporządzenie [1927] Prezydenta Rzeczypospolitej o wydzielaniu z administracji państwowej przedsiębiorstw państwowych, przemysłowych, handlowych i gónniczych oraz o ich komercjalizacji. Na jego podstawie z administracji państwowej wydzielono np. niektóre zakłady wojskowe (Państwowe Wytwórnie Uzbrojenia, Państwowe Zakłady Lotnicze, Państwowe Zakłady Inżynierii, Państwowe Zakłady Umundurowania) [Stawecki, 1971, s. 217-221]. Oznaczało to nadanie przedsiębiorstwom osobowości prawnej i wyeliminowaniu ich z grupy „A” budżetu państwa, w której mieściły się wydatki na administrację państwową [Głąbiński, 1933, s. 11; Rybarski, 1935, s. 54]. 12 Chodziło tu o zagraniczne spółki z o.o. i spółki akcyjne, które mogły być dopuszczone do działalności na terenie Polski tylko za zezwoleniem ministra przemysłu i handlu, w przypadku akcyjnych także ministra skarbu. Wymogiem było posiadanie kapitału zakładowego, przeznaczonego wyłącznie na działalność w Polsce, który nie mógł być niższy niż minimum ustanowione dla spółek powstałych w kraju, czyli 10 tys. zł (spółka z o.o.) i 250 tys. zł (spółka akcyjna), oraz wpisanie spółki do rejestru handlowego [Rozporządzenie, 1928; Rozporządzenie, 1934]. 
Ważną zasadą był obowiązek wykorzystania przy realizacji zamówienia miejscowej siły roboczej („sił krajowych”), surowców oraz innych wyrobów. W przypadku niedostatecznej ich ilości w kraju, przy wcześniejszym całkowitym wykorzystaniu miejscowych rezerw, wykonawca mógł posiłkować się źródłami zagranicznymi. Rozporządzenia odpowiednich ministrów miały zadekretować konieczność wykonania zamówień tylko $\mathrm{z}$ surowców pochodzenia krajowego lub w przypadku niemożności spełnienia tego wymogu, określić wymaganą ilość ich domieszki.

Wszystkie pozostałe kwestie miały rozstrzygnąć rozporządzenia wykonawcze oraz przepisy specjalne poszczególnych ministrów. Koła gospodarcze powitały uchwalenie ustawy z ulga jako krok na drodze ku jednolitości i uproszczeniu tego prawa. Jednak jej ramowość powodowała, że do czasu uchwalenia przepisów wykonawczych w wielu kwestiach proceduralnych posługiwano się dotychczasowymi rozwiązaniami ${ }^{13}$.

\section{Przepisy wykonawcze}

Rozporządzenie wykonawcze do ustawy ukazało się dopiero w 1937 r. [Rozporządzenie, 1937]. Długi czas oczekiwania na przepisy wykonawcze, które umożliwiłyby stosowanie ustawy, tłumaczony był licznymi rozbieżnościami w stanowiskach rządu i sfer gospodarczych, głównie samorządu przemysłowo-handlowego. Najważniejszą osią sporu było wybranie preferowanego przez prawodawcę trybu procedury przetargowej14. Jeszcze przy pracach nad ustawą rząd zdecydowanie opowiadał się za przetargiem nieograniczonym. Izby przemysłowo-handlowe optowały zaś za ustaleniem prymatu przetargu ograniczonego, co dawałoby przedsiębiorcom większą swobodę wyboru15. Druga połowa lat trzydziestych to jednak okres dużej roli i wpływu rządu na kształt uchwalanego wtedy ustawodawstwa gospodarczego. Rozwiązania przyjęte w rozporządzeniu realizowały oczekiwania władzy wykonawczej.

Oprócz konfliktów na linii rząd - samorząd gospodarczy również ustalenie jednolitego stanowiska wewnątrzrządowego nie było łatwe ${ }^{16}$. Uzgodnienia międzyministerialne bardzo często zabierały dużo czasu. Każdy resort przyzwyczajony był

\footnotetext{
13 Ustawa formalnie uchylona została dopiero po wojnie. Nastapiło to w art. 12, pkt 2 ustawy [1948] o dostawach, robotach i usługach na rzecz Skarbu Państwa, samorządu oraz niektórych kategorii osób prawnych [aśkiewicz, 1949].

${ }^{14} \mathrm{Jak}$ pisał T. Kołodziej: , ,[...] nawet przy uzgodnieniu poglądów, odnoszących się w gruncie rzeczy do szczegółów, pozostawały nierozstrzygnięte kwestie zasadnicze, dotyczące istoty przetargów" [Przepisy..., 1937, s. 4].

15 Bardzo aktywna w tej sprawie była np. Izba Przemysłowo-Handlowa w Krakowie. Tradycja jej aktywności w dziedzinie zamówień publicznych sięgała czasów monarchii austro-węgierskiej [Kargol, 2003, s. 126-130].

16 Według T. Kołodzieja: „Powody, jakie opóźniły realizację postanowień [...] ustawy, były - jak fama głosi - takie, że zainteresowane resorty ministerialne nie byly w stanie w szybszym tempie uzgodnić swe poglądy" [Przepisy..., 1937, s. 4].
} 
do swoich rozwiązań, z których korzystał wcześniej. Osiagnięcie kompromisu znacznie przedłużało prace nad nowym prawem.

Rozporządzenie wykonawcze było dość obszernym aktem. Liczyło 50 paragrafów, w których szczegółowo omówiono warunki i tryby udzielania w Polsce zamówień publicznych. W dużej mierze posiłkowano się funkcjonującymi już rozwiązaniami, które zawarte były wcześniej w projekcie z 1927 r. Przewidziano pieć trybów udzielania zamówień, z których trzy były przetargowe. Zaliczono do nich pisemny przetarg ofertowy nieograniczony, pisemny przetarg ofertowy ograniczony i publiczny przetarg ustny. Dwa pozostałe tryby to postępowania bez przetargu, czyli zamówienia z wolnej ręki, oraz zakupy bezpośrednie za zwykłym rachunkiem.

Do najważniejszych jego postanowień zaliczyć należy ostateczne zatwierdzenie prymatu przetargu nieograniczonego nad innymi formami realizacji zamówień. Z tej zasady wynikało szereg ważkich konsekwencji, w szczególności zaś powszechność i jawność zawiadomień o przetargach publicznych. Niewątpliwym sukcesem rządu było obalenie dominacji zasady wybierania ofert z najniższą ceną. Konieczność brania pod uwage całokształtu warunków zgłaszanych przez oferentów, przede wszystkim ich solidności, oddalała wizję wybierania najtańszych i niesolidnych wykonawców [Piasecki, 1938, s. 83-89]. Temu celowi służyło także zablokowanie w zasadzie możliwości przeprowadzenia dodatkowego przetargu (po zakończeniu głównego), mającego na celu obniżenie ceny zamówienia. Zgłaszanie przez oferentów tzw. cen deficytowych było częstym i bardzo szkodliwym zjawiskiem. Dezorganizowało bowiem plan realizacji zamówień, przeciagając $\mathrm{w}$ nieskończoność procedurę wyboru wykonawcy, który byłby w stanie dokończyć realizację zamówienia. Pozostałe tryby były dopuszczalne po zaistnieniu przewidzianych w rozporządzeniu okoliczności.

Bardzo ważną zasadą było także zdecentralizowanie dostaw. Większe zamówienia (,znaczniejszych rozmiarów”) miały być udzielane w sposób uwzględniający potrzeby wszystkich okręgów gospodarczych państwa. Taki sam cel miało przyjęcie postanowienia o przyznaniu prawa pierwszeństwa rynkowi miejsca przeznaczenia zamówienia. Biorąc pod uwagę nierównomierny rozwój gospodarczy Polski międzywojennej, taka regulacja dawała możliwość częściowego chociaż wyrównania szans. W tym kierunku szły też zapisy dotyczące pierwszeństwa rolników w zakresie dostaw produktów rolnych ${ }^{17}$, a rzemieślników - w zakresie dostaw wyrobów rzemieślniczych. Przyjęcie pojęcia tzw. sezonu martwego w przemyśle i rzemiośle, w którym miały być wykonywane zamówienia, oraz udzielanie zamówień rolnikom w okresach po żniwach i wykopkach było przejawem stworzenia preferencji dla tych grup wykonawców.

\footnotetext{
17 Bezpośrednich zakupów u producentów rolnych dokonywało wojsko. Organy za to odpowiedzialne (np. w zakresie zakupu zboża - Intendentury Dowództw Okręgów Korpusu) zawierały umowy szczegółowe bez względu na wysokość ceny kupna, ponosząc za to pełną odpowiedzialność [Szymański, 1937, s. 200; Szymański, 1938, s. 203].
} 
Rozporządzenie było nowoczesnym aktem prawnym, w którym uwzględniono najlepsze osiagnięcia doktryny w zakresie organizowania procedur przetargowych oraz potrzeby i wymagania praktyczne życia gospodarczego.

\section{Podsumowanie}

Przedwojenne prawo zamówień publicznych tworzone było w warunkach licznych trudności gospodarczych, z jakimi borykało się państwo polskie. Wynikały one z konieczności połączenia trzech dzielnic w jeden organizm państwowy. $\mathrm{Na}$ to nakładały się problemy generowane przez wielki kryzys gospodarczy lat trzydziestych, który w rolniczej Polsce trwał dłużej. Polityka rządu ukierunkowana była na stworzenie prawa, które ujednoliciłoby działania zamawiających i wykonawców na terenie całego kraju oraz stworzyło warunki do rozwoju krajowego rynku zamówień publicznych. Prawo to tworzono z intencją ochrony przede wszystkim polskiego rynku i miejscowych przedsiębiorców i dlatego koniecznością było przyjęcie przez ustawodawcę zasady stosowania preferencji krajowych. Takie rozwiązania występowały w dawnym prawie zaborczym wszystkich zaborów, na którym się wzorowano, oraz w innych państwach. Działania protekcyjne, których celem była ochrona krajowego rynku, mieściły się wtedy w kanonie działań interwencyjnych państwa. Zasada prymatu przetargu nieograniczonego nad innymi formami realizacji zamówienia ustawodawca otwierał wielu wykonawcom możliwość ubiegania się o zamówienie. Zdecentralizowanie dostaw uwzględniać zaś miało potrzeby różnych regionów kraju oraz różnych grup przedsiębiorców.

Prawo to stało się punktem wyjścia dla nowych rozwiązań przyjętych w Polsce w pierwszej połowie lat dziewięćdziesiątych.

\section{Literatura}

Dekret, 1918, Dekret z dnia 7 grudnia 1918 r. w przedmiocie utworzenia Urzędu Rozdzielczego w celu centralizacji zamówień rządowych, Dz.P.P.P. 1918, nr 19, poz. 55.

Dekret, 1919, Dekret w przedmiocie utworzenia Prokuratorii Generalnej Rzeczypospolitej Polskiej, Dz.P.P.P. 1919, nr 14, poz. 181.

Dostawy $i$ roboty na rzecz zwiazków samorzqdowych. Zbiór przepisón ogólnych i warunków technicznych, 1939, Samorządowy Instytut Wydawniczy, Warszawa.

Encyklopedia bistorii Drugiej Rzeczypospolitej, 1999, Wydawnictwo Wiedza Powszechna, Warszawa.

Głąbiński S., 1933, Zarys nowszego ustawodawstwa skarbowego w Polsce, nakładem autora, Lwów.

Grata P., 2009, Monopole skarbowe w polityce podatkowej Drugiej Rzeczypospolitej, Wydawnictwo Uniwersytetu Rzeszowskiego, Rzeszów. 
Jaśkiewicz Z., 1949, Dostany $i$ roboty w nonym ujeciu prawnym, Zakład Skarbowości UMK w Toruniu, Toruń.

Kargol T., 2003, Izba Przemystowo-Handlowa w Krakowie w latach 1850-1939. Drieje ludzie - polityka, Towarzystwo Wydawnicze „Historia Iagellonica”, Kraków.

Kłoczewski Z., 1987, Polska gospodarka wojskowa 1918-1939 (zarys systemu), Wydawnictwo MON, Warszawa.

Landau Z., 1974, Zasieg kartelizacji przemystu w Drugiej Ržecsypospolitej, „Kwartalnik Historyczny", t. 81, z. 4, s. 789-817.

Landau Z., 1989, W arunki bytu ludności, [w:] Problemy gospodarcze Drugiej Rzecsypospolitej, Kozłowski K. (red.), Państwowe Wydawnictwo Ekonomiczne, Warszawa.

Partyka K., 1931, Na marginesie przepisón o dostawach wojskonych, „Przegląd Intendencki”, z. 2, s. 20-26.

Pączewski L., 1921, Budžety wojskowe Polski a państwa obych, „Bellona”, z. 8, s. 715-727.

Piasecki E., 1938, Wezwanie do sktadania ofert, „Przegląd Intendencki”, z. 3, s. 82-91.

Podolska-Meducka A., 2008, System swriadczeń wojennych w Polsce 1918-1921. Przeglad ustawodawstwa, „Przegląd Historyczno-Wojskowy”, nr 5, s. 111-146.

Podolska-Meducka A., 2011, Od wojny do wojny. System świadczeń wojennych w Polsce w latach 1918-1921, Oficyna Wydawnicza SGH, Warszawa.

Projekt dekretu o dostawach, 1927, „Przegląd Intendencki”, z. 3.

Przepisy o dostawach i robotach na rzecz. Skarbu Państwa, samorzadu oraz instytucji prawa publicznego, 1937, oprac. T. Kołodziej, Poznań.

Przepisy o dostawach wojskonych, c:. I - Dostany krajowe. Instrukicja ₹.15 zatacznikami, 1923, Ministerstwo Spraw Wojskowych - Wojskowy Instytut Naukowo-Wydawniczy, Warszawa.

Regulamin Głównego Urzędu Zaopatrywania Armii, Dziennik Rozkazów Ministerstwa Spraw Wojskowych, 1919, nr 33, poz. 2936.

Rozporządzenie, 1927, Rozporządzenie Prezydenta Rzeczypospolitej z dnia 17 marca 1927 r. o wydzielaniu $z$ administracji państwowej przedsiębiorstw państwowych, przemysłowych, handlowych i górniczych oraz o ich komercjalizacji, Dz.U. R.P. 1927, nr 25, poz. 195.

Rozporządzenie, 1928, Rozporządzenie Rady Ministrów z dnia 20 grudnia 1928 r. w sprawie warunków dopuszczenia zagranicznych spółek akcyjnych albo komandytowo-akcyjnych do działalności na obszarze Rzeczypospolitej, Dz.U. R.P. 1928, nr 103, poz. 919.

Rozporządzenie, 1934, Rozporządzenie Rady Ministrów z dnia 28 marca 1934 r. o warunkach dopuszczenia zagranicznych spółek z ograniczoną odpowiedzialnością do działania na obszarze Rzeczypospolitej Polskiej, Dz.U.R.P. 1934, nr 31, poz. 281.

Rozporządzenie, 1937, Rozporządzenie Rady Ministrów z dnia 29 stycznia 1937 r. o dostawach i robotach na rzecz Skarbu Państwa, samorządu oraz instytucji prawa publicznego, Dz.U. R.P. 1937, nr 13, poz. 92.

Rybarski R., 1935, Nauka skarbowości, Sekcja Tow. „Bratnia Pomoc”, Warszawa.

Sejm RP III okresu, Druk nr 307, Rzqdowy projekt ustawy o dostawach i robotach państwowych. 
Sejm RP III okresu, Druk nr 617, Rzqdowy projekt ustawy o dostawach i robotach na rzecz. Skarbu Państwa, samorzqdu oraz instytucji prawa publicznego.

Sosabowski S., 1927, Gospodarcza konstytucja obrony państwa, „Bellona”, z. 1, s. 43-60.

Sprawozdanie, 1931, Sprawozdanie stenograficzne z 33 posiedzenia Sejmu RP III okresu z dnia 20 października 1931 r.

Sprawozdanie, 1932, Sprawozdanie stenograficzne z 72 posiedzenia Sejmu RP III okresu z dnia 13 grudnia 1932 r.

Sprawozdanie, 1933a, Sprawozdanie stenograficzne z 43 posiedzenia Senatu RP III okresu z dnia 15 lutego 1933 r.

Sprawozdanie, 1933b, Sprawozdanie stenograficzne z 77 posiedzenia Sejmu RP III okresu z dnia 27 stycznia 1933 r.

Stawecki P., 1971, Z driejów przemystu wojennego w II Rzeczypospolitej, „Wojskowy Przegląd Historyczny", nr 3 (cz. II), s. 217-258.

Szymański S., 1937, Bezpośrednie qakupy wojska u producentón rolnych. Wymowa cyfr i wnioski, „Przegląd Intendencki”, z. 3, s. 200-210.

Szymański S., 1938, Zakupy plodów rolnych u producentów. Aktualne dane statystyczne, „Przegląd Intendencki”, z. 3, s. 203-210.

Uchwała, 1920, Uchwała Sejmu RP z dnia 30 stycznia 1920 r. w sprawie uchylenia mocy dekretu z dnia 7 grudnia 1918 r. w przedmiocie utworzenia Urzędu Rozdzielczego w celu centralizacji zamówień rządowych, Dz.U. R.P. 1920, nr 10, poz. 55.

Ustawa, 1919a, Ustawa z dnia 31 lipca 1919 r. w przedmiocie utworzenia Prokuratorii Generalnej Rzeczypospolitej Polskiej, Dz.P.P.P. 1919, nr 65, poz. 390.

Ustawa, 1919b, Ustawa z dnia 11 kwietnia 1919 r. o utworzeniu Głównego Urzędu Zaopatrywania Armii, Dz.P.P.P. 1919, nr 32, poz. 265.

Ustawa, 1920, Ustawa z dnia 18 grudnia 1920 r. w przedmiocie reorganizacji sprawy zaopatrywania armii, Dz.U.R.P. 1921, nr 6, poz. 33.

Ustawa, 1933, Ustawa z dnia 15 lutego 1933 r. o dostawach i robotach na rzecz Skarbu Państwa, samorządu oraz instytucji prawa publicznego, Dz.U. R.P. 1933, nr 19, poz. 127.

Ustawa, 1948, Ustawa z dnia 18 listopada 1948 r. o dostawach, robotach i usługach na rzecz Skarbu Państwa, samorządu oraz niektórych kategorii osób prawnych, Dz.U. R.P. 1948, nr 63, poz. 494.

Zweig F., 1944, Poland between Two Wars. A Critical Study of Social and Economic Changes, Seeker\&Warburg, London.

Żelaski S., 1937, Dostawy i roboty dla wojska, „Przegląd Intendencki”, z. 2, dodatek. 